\title{
MEGÉRTÉS AZ EGYÜTTMÜKÖDÉS SZOLGÁLATÁBAN 2. RÉSZ - EGY INTERPRETATÍV SZERVEZETKUTATÁS TAPASZTALATA: A LUPUS ALBUS OSZTÁLY ESETE
} UNDERSTANDING IN THE SERVICE OF COLLABORATION (PART 2) - THE EXPERIENCE OF AN INTERPRETATIVE STUDY: THE CASE OF THE LUPUS ALBUS DEPARTMENT

A cikkben egy magyarországi újszülött intenzív osztályon az együttműködés helyi jelentésének feltárását célzó kvalitatív kutatást mutat be a szerző. Ezzel kettős célja van: egyrészről egy szervezeti jelenség megértő vizsgálata, másrészről a vizsgálati mód tapasztalaton keresztüli bemutatása. A kutatás eredménye példát ad arra, hogy hogyan jöhet létre mély megértés, ami későbbi szervezeti változás kiindulópontját jelentheti. A megértés folyamatát olyan alternatív kvalitatív kutatási eszközök is támogatták, mint például a térelemzés vagy a metafora. A tanulmány továbbá kiemeli annak fontosságát, hogy egy kórházi osztályon a helyi jelentés kutatása során a hozzátartozók bevonása is alapvető fontosságú.

Kulcsszavak: együttmüködés, egészségügy, kvalitatív kutatás, interpretatív paradigma

This article is about the experience of a qualitative study focusing on the meaning of collaboration at a neonatal intensive care unit. The author's goal is twofold: on the one hand to deeply understand an organizational phenomenon; on the other hand, to provide a detailed report of the experience of the qualitative research method. The outcome of research exemplifies how deep understanding can be gained which can be the starting point of organizational change. The process of understanding was also supported by alternative methods such as interpretation of physical surroundings and metaphor. The article also emphasises that during a study research in a hospital department involving relatives is essential.

Keywords: collaboration, health care, qualitative research, interpretative paradigm

\section{Finanszírozás/Funding:}

A szerző a tanulmány elkészítésével összefüggésben nem részesült pályázati vagy intézményi támogatásban.

The author did not receive any grant or institutional support in relation with the preparation of the study.

\section{Szerző/Author:}

Verdes Tamás, PhD-hallgató, Budapesti Corvinus Egyetem, (tamas.verdes@uni-corvinus.hu)

A cikk beérkezett: 2020. 06. 04-én, javítva: 2020. 09. 14-én, elfogadva: 2020. 09. 24-én.

This article was received: 04. 06. 2020, revised: 14. 09. 2020, accepted: 24. 09. 2020.

\footnotetext{
$\mathrm{C}$ ikksorozatom második részében bemutatom azt az együttműködésre irányuló, megértő szándékú vizsgálatot, amit egy magyarországi kórházi osztályon valósítottam meg. Előző írásomban (Verdes, 2020) bemutatott szakirodalmi áttekintésem célja az egészségügyi szervezetekben tapasztalható együttmüködés és bevonás témaköreinek jelentésvilágába való betekintés volt. A megismert tapasztalatok bemutatásával felhívtam a figyelmet a rendszerszemlélet, a kultúrához való alkalmazkodás és a megértő közelítés fontosságára. Az egészségügyi együttmüködés témájában megismert fogalmak (pl. orvos-páciens kapcsolat és kommunikáció, páciensközpontúság)
}

kapcsán világossá vált, hogy ezek értelmezése korántsem kézenfekvő. A különböző modellek, definíciók, sőt a hatások ellentmondásos tapasztalata arra ösztönzött, hogy nem az általános választ, hanem a helyit érdemes megismerni: azt, hogy egy adott kórházi osztályon mit jelentenek ezek a fogalmak.

Az elvégzett kutatás bemutatásával célom kettős. Egyfelöl a szervezetek életének egy fontos jelenségével, az együttmüködéssel foglalkozom, ennek a fogalomnak a helyi jelentését kutatom. Másfelöl viszont szándékom egy, az interpretatív szervezetelméleti paradigma talaján álló kvalitatív kutatás folyamatának részletes bemutatása. 
Kutatásom terepe egy magyarországi újszülött intenzív osztály, ahol az együttmüködés és bevonás mindennapos, hosszabb távú szükséglet. A szervezet és tagjai anonimitásának tiszteletben tartása miatt a továbbiakban egy fantázianevet használok: Lupus Albus Osztály. ${ }^{1}$ Arra hívom meg az Olvasót, hogy lépjen be ebbe a világba. Szándékom szerint a kutatás mellett a bemutatás módja is a megértés egy sajátos minőségét teszi lehetővé: tudás szerzését az ,átélés”, beleérzés segítségével.

Írásomban először a tágabb kereteket (alapállás, kutatás célja, módszertana), majd a megvalósult kutatást mutatom be.

\section{Kutatói alapállás - Az interpretatív paradigma}

Kutatói közelítésem és a megvalósult kutatás az interpretatív szervezetelméleti paradigma talján áll. Meggyőződésem szerint a szervezeti valóság nem tölünk függetlenül és rajtunk kívül (objektíven) létező, hanem bennünk és általunk, a közösen létrehozott (konstruált) helyzetekben, cselekvésekben, a nyelvben, a tudat rejtettebb dimenzióiban él. Éppen ezért a szervezeti elakadásokra, jelenségekre és az itt bemutatott konkrét osztályra vonatkozó vizsgálódásomat is az adott helyen és időben való megértés és a közös jelentések (interszubjektivitás) feltárása vezérli (vö.: Gelei, 2006; Burrell \& Morgan, 1979; Wollnik, 1995).

Bár nem a témakör határozza meg a ,szemüveget” (amelyen keresztül látjuk a világot) vagy azt, hogy milyen módszertant alkalmazunk, de a kutatói alapállás meghatározza azt, hogy mi lesz a célunk, mi válik fontos kérdéssé.

\section{A kutatás célja}

Kutatásom célját a következők szerint tudom összegezni.
- A Lupus Albus Osztály érintettjeivel közvetlen kapcsolatba kerülve kívántam a „külső” szemlélő számára könnyen felfedezhető szervezeti jelenségektől (események, interakciók) a mögöttes értelmezésekhez eljutni. Megérteni szerettem volna az adott közeget, megismerni a közös jelentéstartalmakat, különös hangsúllyal az együttmüködésen az osztályon dolgozók és a hozzátartozók között.

- „Akik kapcsolatba kerülnek a szervezettel, egyben részt is vesznek a szervezeti valóság alakításában, a közös szervezeti jelentésekről szóló diskurzusban" (Gelei, 2006, p. 89). Ennek megfelelően az osztályon dolgozók mellett a szülöket (főleg az édesanyákat) is be kívántam vonni a vizsgálat során - és persze én magam is részt vettem ebben az előbb említett párbeszédben.

- A saját tapasztalatommal, közelítésemmel és megértésemmel a szervezet müködéséhez is hozzá akartam járulni az ,ügyfél” nézőpontjának bevonásával. Ezzel céllá vált egy lehetséges későbbi diagnózis, szervezetfejlesztői folyamat kezdetének megalapozása. Próbát tettem tehát arra, hogy példát, ötletet adjak hasonló projektekhez egészségügyi szervezetekben.

Nem volt cél ugyanakkor egy fejlesztői diagnózis elkészítése, vagy az osztályon való együttmüködés minősítése (összehasonlítása más osztályokkal), sem a vizsgálat alapján modellek, elméletek igazolása vagy felállítása.

\section{Kutatási kérdések és módszertani közelítés}

A kvalitatív kutatásra ugyan nincs általánosan elfogadott meghatározás, de a definíciók közös jellemzőinek egyike az interpretatív alapállás (Mason, 2005, p. 13). A mélyelemzést helyeztem elötérbe, így számomra nem a környezet volt fontos, inkább belülröl közelitettem. Azt vizsgál-

\section{Kutatási kérdések és alkalmazott módszertanok}

\begin{tabular}{|c|c|c|}
\hline Kutatási kérdések & Adatforrás és módszer & Indoklás \\
\hline $\begin{array}{l}\text { Jellemzően mit jelent az együttmüködés } \\
\text { a dolgozók és a szülők számára a Lupus } \\
\text { Albus Osztályon? } \\
\text { Milyen közös és eltérö értelmezésminták } \\
\text { vannak? }\end{array}$ & $\begin{array}{l}\text { Az osztályon dolgozó orvosok, } \\
\text { nővérek és a szülök elbeszélé- } \\
\text { sei: félig strukturált mélyinter- } \\
\text { júk. }\end{array}$ & $\begin{array}{l}\text { A személyes beszélgetés során lehetőség nyílik az együtt- } \\
\text { működésben érintettek értelmezéseit megismerni. }\end{array}$ \\
\hline $\begin{array}{l}\text { Mik a tipikus, jellemző viselkedések és } \\
\text { tettek? }\end{array}$ & $\begin{array}{l}\text { Az osztály napi múködése: } \\
\text { résztvevő megfigyelés. }\end{array}$ & $\begin{array}{l}\text { Az érintettek lehető legkisebb befolyásolása mellett meg- } \\
\text { tapasztalható a hétköznapi valóságuk (rutinjuk), aminek } \\
\text { értelmezése már közös feladat. }\end{array}$ \\
\hline Kinek mi az érdeke? & $\begin{array}{l}\text { Tájékoztató anyag: } \\
\text { dokumentumelemzés. }\end{array}$ & $\begin{array}{l}\text { Az írásos anyagokban tetten érhetőek lehetnek a kifejezett } \\
\text { érdekek, amelyek összevethetők más módszertanok ered- } \\
\text { ményével. }\end{array}$ \\
\hline $\begin{array}{l}\text { Hogyan viszonyulnak egymáshoz, a } \\
\text { helyzetekhez, feladatokhoz? }\end{array}$ & $\begin{array}{l}\text { Az ápolás, kapcsolattartás fizi- } \\
\text { kai közege: térelemzés. }\end{array}$ & $\begin{array}{l}\text { A terek (lehetőségei, korlátai) megismerése hozzájárulhat } \\
\text { az érintettek helyzetekhez való viszonyulásának, érdekei- } \\
\text { nek mögöttes okainak megértéséhez. }\end{array}$ \\
\hline $\begin{array}{l}\text { Mik a tipikus gondolatok, jellemző érzé- } \\
\text { sek? }\end{array}$ & $\begin{array}{l}\text { Orvosok, nővérek, szülők: } \\
\text { metafora (interjúban). }\end{array}$ & $\begin{array}{l}\text { Az eddigieket kiegészítendő és mélyítendő a tudatalatti, } \\
\text { a háttérben lévő gondolatok, érzések is kifejezésre juthat- } \\
\text { nak. }\end{array}$ \\
\hline
\end{tabular}

Forrás: Mason (2005, p. 32) alapján saját szerkesztés 
tam, hogy miben érhetem tetten a mögöttes tartalmakat, amelyek terei egymástól nem elválaszthatóan: a szervezeti tagok tudatos gondolatai (válaszok, elvárások), a cselekvések, nyelvhasználat, érzések ( $\mathrm{pl}$. félelmek, sikerélmények), de a tudatalatti is (pl. belső képek, álmok).

Ezek fényében az 1. táblázatban választ adok arra a kérdésre, hogy a céljaim elérése és a kérdések megválaszolása érdekében milyen módszertanokra támaszkodtam és miért.

Összességében arra kerestem választ, hogy a mélyebb megértéssel a témában hogyan lehet hozzájárulni az együttmüködés fejlesztéséhez?

A táblázat röviden példázza, hogy a különböző módszertanok külön-külön hogyan szolgálták az együttmüködés megértését. Ezek együttes alkalmazásával (trianguláció) az volt a célom, hogy a különböző forrásokból származó információk az interjúk értelmezését kiegészítsék, esetlegesen rávilágítsanak új szempontokra.

Mivel a mély megértéshez közel áll a tudatalatti feltárása, az alternatív technikák világába is betekintettem. „A projektív technikák esetében megfogalmazott feltételezés, hogy a nem tudatos, de legalábbis eddig közvetlenül meg nem fogalmazott vágyak és érzelmek feltárhatók" (Horváth, 2015, p. 280). Segíthetnek leküzdeni kommunikációs korlátokat, valamint a direkt rákérdezéshez képest a társadalmilag elvárt válaszok vagy az „önfényezés” elkerülésében (Horváth, 2015). Ezen a csoporton belül az asszociatív technikák alkalmazása egy célravezető eszköz, ahol „a válaszadók egy megadott ingerre reagálnak - legyen az szó, kép, szimbólum -, és elmondják, hogy mi az első szó, kép, ami eszükbe jut" (Horváth, 2015, p. 295). Arra kértem az érintetteket, hogy egy állattal jelenítsék meg az osztályt. Az így kapott állatmetafora felhasználása mélyítette és kiegészítette a megértésemet.

\section{Előfeltevések}

Legfontosabb előfeltevéseim megfogalmazásával nem igazolandó vagy cáfolandó célokat állítok fel, hanem interpretatív meggyőződésemből fakadóan fontosnak tartottam, hogy kimondjak olyan gondolatokat, amelyek torzíthatják a megértő értelmezést (a torzító vagy perspektivikus szubjektivitásról lsd. Kvale, 2009). Így gondolkodtam:

- A ,hogyan müködik?” kérdés mellett a „hogyan lehetne jobb?" is foglalkoztat. A kutatói szerepen túl van bennem tehát vágy a fejlesztésre, azzal az előfeltevéssel (személyes élményekből táplálkozva), hogy „vannak nehézségek az együttműködéssel és bevonással". Ez torzító lehet annyiban, hogy az elakadásokat helyezem elötérbe.

- Az osztályon a szigorú szabályok és kötött szerepek mögött ezektől eltérő, informális működést is feltételezek.

- A dolgozók a fizetésben és a rendszerben találják meg elsők között a problémák okát. Ugyanakkor szerintem a témát tekintve a megoldás kulcsa nem pénzügyi kérdés.

- A szülőkről azt gondolom, hogy félnek, aggódnak a gyerekük miatt, ami feszültséget, türelmetlenséget okoz, és ez sok konfliktus alapja lehet. Az osztály részéröl pedig az erre adott (pl. feszült) reakció nem pusztán a pillanatból forrásozik, hanem jelen van a szervezetben máshol is (,displacement” jelenség lsd. Long, 2001).

E feltételezéseknek nem a beteljesítése, hanem tudatos kezelése volt a cél.

\section{A kutatás folyamata}

A tudatosság mellett a kivitelezés rugalmassága is a kvalitatív kutatás jellemzője. A „terep” megismerése előtt nem volt meghatározott kvótám az interjúalanyok számára vonatkozóan. Elöljáróban mindhárom érintett-csoport (orvos, nővér, szülö) bevonását és a kérdésekre vonatkozó elméleti telítettség elérését fogalmaztam meg elvárásként.

Mason (2005, p. 49) alapján nem adatgyüjtésről beszélek, hanem adatgenerálásról, kifejezve, hogy kutatóként nem maradhatok független a kutatás tárgyától, nem lehetek semleges szemlélő. A létrejövő adatokat így jellemzően „interpretatív értelemben” olvastam, tehát nem csupán szó szerinti tartalmukban (Mason, 2005, p. 69). Adatforrásként pedig a következőkre tekintettem:

- az interjúalanyok kérdésimre adott válaszai,

- beszámolóik a megéléseikről, érzéseikről,

- állatmetaforák,

- a fizikai tér és

- a tájékoztató füzet általam történő értelmezése.

A következőkben módszertanonként írok először az adatgenerálás majd a feldolgozás folyamatáról.

\section{Interjúk}

Adatgenerálás. Kutatásom leghangsúlyosabb részét az érintettekkel folytatott beszélgetések adták. A mintavétel teljes keretének a szülökön kívül az osztályon dolgozó orvosokat, nővéreket tekintettem, akik kapcsolatba kerülnek az ott ápolt kisbabák szüleivel. A legteljesebb képet kétségtelenül az osztályon dolgozók mindegyikének ( 9 orvos, 25 nővér) megkérdezése adta volna, de időbeli korlátok miatt ez nem valósult meg.

Feltételeztem, hogy szerepükből fakadóan meghatározó értelmezéssel rendelkeznek (aminek kiemelt vizsgálata most nem célom), így az osztályvezető orvos, a főnővér és helyettesének bevonását fontosnak tartottam. A többiek kiválasztása véletlenszerü volt, attól függően, hogy ki tudott éppen időt szakítani a beszélgetésre.

A szülők kiválasztásában már a főnővér és egy orvos támogatott. Nem én szólítottam meg őket közvetlenül, tiszteletben tartva azt a nehéz helyzetet, amelyet éppen megélnek vagy megéltek. Ez a kiválasztás azonban olyan édesanyákra szűkítette a kört, akik a körülményekhez képest „könnyebb” helyzetben voltak, vagy már szerencsés módon gyógyulással, hálával tudhatják maguk mögött az osztályon szerzett tapasztalatot.

A kutatás körülbelül egy hónapos időszakában több mint tíz órát töltöttem interjúzással, amelynek során négy 
édesanyát, öt orvost, egy rezidenst és egy orvostanhallgatót, illetve öt nővért értem el saját közegükben (lsd. jegyzetek). Az interjúkat hangfelvételen rögzítettem, közben rövid jegyzeteket készítettem (fontos témákról, benyomásokról, körülményekről).

Az interjúk során mindenkinek feltett kérdéseim:

- Mi jut eszébe arról, ha azt mondom, hogy az osztály dolgozói és a szülők közötti együttmüködés? Mit jelent ez Önnek?

- Milyen érzések kerülnek elő Önben ennek kapcsán?

- Kinek mi az érdeke ebben az együttmúködési folyamatban?

- Milyen állattal tudná azonosítani az osztályt (beleértve a szülőket is)?

Adatfeldolgozás. A hangfelvételeket, jegyzeteket begépeltem, így könnyebbé vált a kereshetőség és a feldolgozás. A 60 oldalnyi szöveges anyagot színes kiemelésekkel, megjegyzésekkel láttam el, illetve a formálódó kategóriák mentén kigyüjtöttem a témákhoz kapcsolódó fö kifejezéseket, benyomásokat (miközben nem ragaszkodtam ezek elválaszthatóságához). A rendszerezés folyamatosan alakuló munka volt: a gondolatokról készített „,térképen” felbukkantak újabb, fontosabb elemek, amelyek szövegrészletek újraolvasását, vagy az élmények újragondolását tették szükségessé. Egyes elemek pedig, amelyek elöször fontosnak tüntek, idővel háttérbe szorultak. Az idézetek beemelése, illetve a következtetések levonása előtt ismét ellenőriztem a szövegkörnyezetet, jegyzeteket és felidéztem az emlékeket.

\section{Dokumentumelemzés}

A dokumentumok közül egy szülöknek szánt tájékoztató füzetet vizsgáltam meg a következő kérdések mentén. Miről szól a szöveg? Milyen hangsúlyos témákat érint, ez alapján mi lehetett fontos a készítőinek? Milyen a hangulata? Mit sugall a kinézete (képek, formázás)? Mindez hogyan viszonyul a többi módszertan során megismertekhez?

\section{Résztvevő megfigyelés}

Körülbelül 7 órát töltöttem megfigyeléssel a helyszínen: legtöbbször az osztály egy központi pontján elhelyezkedö széken, illetve a konyhában. Ilyenkor megfigyeltem eseményeket (pl. reggeli átadás), párbeszédeket, viselkedéseket, spontán beszélgetésekbe keveredtem. Ezekről jegyzeteket készítettem, melyeket szintén begépeltem.

Minderre résztvevő megfigyelésként tekintek, hiszen nem gondolom, hogy csak megfigyelö voltam, és én vagy a dolgozók függetlenek tudtunk volna maradni a helyzettől (Mason, 2005, p. 81).

A többi módszertan adatainak feldolgozása után a jegyzeteket elővéve, az emlékeket felidézve gondoltam végig, hogy a megfigyeléseim hogyan viszonyulnak az addig összegzett tapasztalatokhoz.

\section{Térelemzés}

Külön időt szenteltem annak, hogy szemügyre vegyem a kórház épületét és a megfigyelések, interjúk közben is ké- szítettem jegyzeteket: benyomások, érzések, tények a fizikai környezetről. A helyszínen készítettem egy vázlatot az osztály alaprajzáról, amelyet később számítógépen is megrajzoltam.

A feldolgozás során a térrel kapcsolatos benyomásaimat és a beszélgetésekben arra utaló megjegyzéseket figyelembe véve vontam le következtetéseket.

\section{A Lupus Albus osztály - A kutatás közegének bemutatása}

\section{"Itt az álmait fogja elgyászolni a szülo"" (Enikő).}

Fő kutatási kérdésem megválaszolásához közeledve bevezetem az Olvasót abba a világba, ahol jártam. Leírok pár fontos információt, ami a később kifejtésre kerülő gondolatok megértését segíti, de emellett célom átadni valamit abból a hangulati, érzelmi közegből, ahol mindezt értelmezni lehet.

A Lupus Albus osztályra nem ,csak” kis súllyal (a nagyon korai szülés következtében), de legtöbbször ezt még súlyosbító betegségekkel kerülnek a kicsik. Ennek következtében az osztályon nagy hangsúlyt fektetnek a higiéniás körülményekre és a látogatás szabályozására. A reggeli átadás, vizitek után a szülők két meghatározott időszakban (nappal és éjszaka) jöhetnek be az osztályra, fél óránkénti beengedéssel és kísérettel.

A babák a szülés után legtöbbször más kórházakból az anyától elkülönítve, előbb érkeznek (majd állapotuk stabilizálása után jellemzően más kórházakba kerülnek át). Szeverényi (2008) ír arról, hogy egy komplikáció nélküli szülés során is milyen trauma érheti az édesanyát, illetve, hogy milyen fontos ott is az együttmüködés. Erre az osztályra kerülve az elszakadás, és a - néha váratlan - koraszülés okozta lelki teher (bizonytalanság, kiszolgáltatottság) nem hagyható figyelmen kívül. Erről mondja egy nővér: „,...amikor magához tér, közlik vele, hogy a gyerekét elvitték egy másik kórházba, ahol lélegeztetik és élet-halál közt van. Azért ezt így egyszerre felfogni, az nagyon..." (Enikö).

A kifejtés során sok szó szerinti idézetet használok (az interjúalanyok álnevének jelölésével, lásd jegyzetek), és nem csupán azért, hogy alátámasszák az állításaimat, hanem, hogy engem kiegészítve segítsék a megértést, igazán átadják azt a miliőt, amelyről szó van. Így ,áll össze a kép".

A kutatás eredményét nem a kutatási alkérdések mentén mutatom be, hanem a helyi jelentések általam feltárt csomópontjai alapján. Ezek választ adnak a kérdésre, hogy mit jelent itt a (hozzátartozókkal való) együttmüködés, ami valóban meghatározó eleme a hétköznapoknak az itt dolgozók szerint is: „Ez nálunk mindig egy sarkalatos kérdés” (Bori). „Hát ez itt majdnem mindent jelent Istenigazából" (Fábián).

Ezek a csomópontok az 1. ábrán ugyan kis halmazokban szerepelnek, de egymástól nem elválasztható, hanem szoros kölcsönhatásban lévő főbb alkotóelemeket jelölnek, amelyek kiemelése az én értelmezésemet tükrözi (nem önkényesen persze). A következőkben a kibontás sorrendjével a megértés elmélyülő folyamatát is megjelenítem. 
1. ábra

Együttműködés

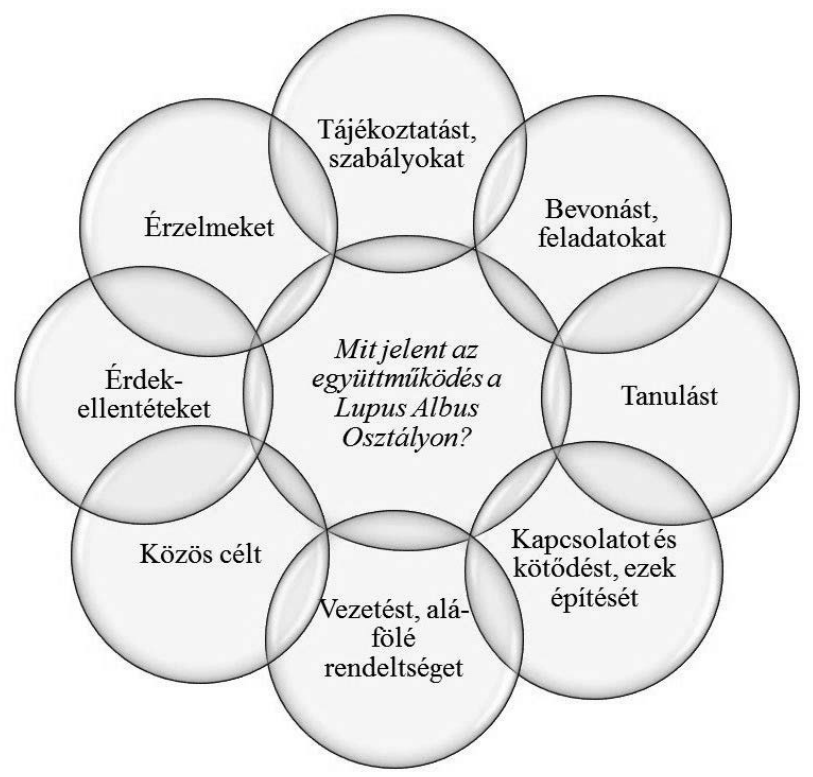

Forrás: saját szerkesztés

\section{Együttműködés a Lupus Albus osztályon - Az interjúk tapasztalata}

\section{Tájékoztatás, szabályok}

\section{„Elsősorban az ember arra kíváncsi, hogy hogy van a gyerkőce, és hogy erről kit tud megkérdezni, kit tud elérni" (Helga).}

A tájékoztatás az egyik kulcspontja az együttműködésnek. A szülök kíváncsiak gyermekük állapotára, és mivel kezdetben nem tudják bekísérni a babát (esetleg az édesapa), illetve távolabb laknak, nagy segítség az osztály telefonos elérhetösége. ,, Az nagyon jó, hogy bármikor be lehet telefonálni, akár a férjemnek is" (Helga).

A szülök számára fontos, hogy ez a tájékoztatás érthető legyen: „Próbálták tényleg elmondani olyan nyelven, hogy a laikusok is megértsék a problémákat" (Helga).

A nővéreknek fontos az a szempont is, hogy a szülöket tájékoztassák az osztály rendjéről (higiénia, látogatási idő). Erre sor kerül az állapotfelmérés és az orvossal való első találkozás után. Ezt a célt szolgálja az általam megvizsgált szülői tájékoztató füzet is.

\section{Bevonás, feladatok}

„Amikor már jobban vannak [a babák], akkor egyre többet vonjuk be öket [a szülőket] a napi ellátási feladatokba" (Enikö).

A bevonás nemcsak információk átadásában, döntésekben, hanem az ellátást tekintve is megvalósul a Lupus Albus Osztályon, ahogy ezt a nővérek mellett az anyukák is kifejezték: ,...megtapasztaltuk azért sok helyen, hogy viziten kiküldik a szülöt, hogy ,nem kell hallani”. Itt bármit elöttünk is mondanak, meg is kérdezik, hogy igy van-e. Próbálnak belevonni azért minket is" (Ildikó).

A szülök bevonása az ápolási folyamatba a gyerekröl való gondoskodás különböző szintjein valósul meg (állapotuktól függően), és ez feladatokat jelent. A baba alapvető fizikai igényeinek kielégítésével kezdődik. 1) Be kell hozni naponta az anyatejet az osztályra. 2) A szülők feladata továbbá a pelenka, testápoló, popsitörlő beszerzése, és ennek a készletnek a szinten tartása. 3) Kezdetben az anyuka lehet, hogy csak beszélni tud a kicsihez, esetleg simogatni. 4) Idővel akár már a fürdetést, tisztába tételt is elintézheti, esetleg bizonyos speciális ellátást is megtanulhat. Fontos látni, hogy ez utóbbi „szintnek” milyen jelentősége van. „Egy szimpla tisztába tevés. Ami más babás anyukáknak természetes dolog, nekünk, akiknek koraszülött és beteg babáink vannak, nekünk ezek hatalmas dolgok" (Nóra).

A bevonás az együttműködés meghatározó része, amelynek megvalósítására jellemzően mindenki törekszik. Egy orvos gondolatából is következik, hogy a szülő ilyenfajta felkészítése a saját maga és a gyerek érdeke egyaránt. „Az ellátásba a szülőt be kell vonnom [...]. Nem adhatok haza addig egy gyereket, amig a szülö nem képes otthon ellátni" (Lajos).

Amellett, hogy a szülők ezzel a dolgozók munkáját segíthetik, a nővér szerint a tehetetlenség-érzés ellensúlyozását is szolgálja mindez. ,Be kell őket [a szülőket] vonni, hogy érezzék, hogy fontosak, és ök is tudnak valamit tenni. Mert, ha csak ott ülök és várok, akkor feleslegesnek érzem magam. És amiatt, mert felesleges vagyok, butaságokat fogok kérdezni, bele fogok kötni mindenkibe, feszült leszek, más is feszült lesz, és akkor vannak a nagy botrányok" (Enikö). Egy édesanya szerint a bevonás fontos ebben a krízishelyzetben, hogy „igazi szülőnek érezhessük magunkat" (Nóra).

A bevonás útjában sokszor a szülők attól való félelme áll, hogy árthatnak a kicsinek. Egy nővér vidám elbeszélése ennek a feladatnak a megoldásáról átvezet minket a tanulás témakörébe. [Apuka fél megfürdetni az ikerpár egyikét, miközben anyuka a másikat fürdeti.] „,Mondtam neki, hogy jó, megfürdetem én. Betettem a gyereket a vizbe. Jaj-mondtam -, apuka, gyorsan megfogná? Nagyon fáj a derekam. Alárakta a kezét a kezem alá, én kihúztam a kezemet, arrébb mentem, anyukával nekiálltunk beszélgetni. Apuka azt mondja: ,és én most mit csinálok?” Mondom, maga fürdet. [Nevetve meséli.] Így meg tudtuk neki mutatni. És akkor elnevette magát és mondta: „ennyire egyszerü fürdetni?" (Enikö).

A bevonás tehát türelmet, felkészülést, tanulást igénylő feladatok ellátását jelenti, de ennek célja nem csupán a nővérek tehermentesítése, hanem a felkészítés is.

\section{Tanulás}

\section{„Meg kell tanulniuk szülőnek lenni" (Enikö).}

Az Osztályon a szülőknek először a rendszert, szabályokat (pl. látogatási idő, kézfertőtlenítés) kell megtanulniuk. Továbbá bármelyik szülő számára kihívást és odafigyelést 
jelent a kisbabájával kapcsolatos teendőinek megtanulása, de ez egy koraszülött, beteg kisbaba esetében fokozottan igaz, hiszen például meg kell tanulniuk, ,,...hogy egy ilyen gyereket nem simogatunk, hanem csak rárakjuk a kezünket" (Enikö).

Az Osztályon megvalósuló együttmüködés tehát egy tanulási folyamat az édesanyák, és egy tanító, felkészítő tevékenység a nővérek számára. ,, Az együttmüködés egyik része, hogy tudja a szülö, [...] hogy mi az, amit elvégezhet" (Lajos).

Az édesanyák igényelték is ezt, a sok kétség között biztonságot adott nekik. „Biztonságban éreztem magam, mert mindig volt mögöttem egy szempár [...]. Ha nem jól csináltam, - nem kioktatásképpen - odajöttek, megmutatták, segítettek” (Nóra). Ez a fajta együttmüködés ráadásul túlmutat az Osztályon eltöltött időszakon, a dolgozóknak meg kell osztaniuk a tudást a szülőkkel. „Én megetethetem, nekem sikerülni fog, de nem én viszem haza. [...] „Nem lehetne, hogy maguk is velem jönnek?” Mondom: nem, anya nem [nevetve]" (Enikö).

Később írok arról, hogy az együttmüködés a dolgozók (a szervezet) számára is tanulást hordoz magában.

\section{Kapcsolat és kötődés, ezek építése}

„Ha nem vonom be az elejétől, akkor idegennek fogja érezni a gyereket" (Enikő).

A bevonás és tanulás ,,alkotóelemeit” szorosan kiegészíti az Osztályon egy fontos szerepet játszó fogalom: a kapcsolat. Az anyák és gyermekek közötti kapcsolat kialakítása kifejezetten célja az együttmüködésnek.

Írtam arról, hogy az édesapa, édesanya ,,megtanul szülőnek lenni", ez azonban nem egy magától értetődő dolog ebben a helyzetben. ,,[Nyílt, 24 órás látogatás mellett, mint külföldön] ... könnyebb a szülöt bevonni a gyermek ellátásába, és könnyebben felnő ahhoz a feladathoz, hogy majd hazavigye a gyermeket. Könnyebben kialakul az a szülö-gyermek kötödés, ami segít abban, hogy akarja ellátni” (Lajos). „,Ne érezzék idegennek. A saját gyerekükkel szemben ne úgy érezzék, hogy ő most beteg, és így távolságot kell tartani” (Petra).

Az együttmüködés a bevonás, tanulás, tájékoztatás mellett arra irányul, hogy egyáltalán létrejöhessen a kapcsolat szülő és gyermek között. Ennek a kapcsolatnak a kialakítását leglátványosabban az úgynevezett „,kenguru módszer" szolgálja, amelynek során az édesanya mellkasára veheti a kicsit, bőr-bőr kontaktus jön létre. Az osztályon ez egy támogatott és a szülöknek javasolt módszer (a baba állapotától függően). Az anyukák is érzékelték a dolgozók törekvését a kapcsolat kialakítására. „,Figyeltek arra, hogy épitgessék a családot. Épitsék az érzést, hogy valaki édesanya. Ez nehéz, ha korán születik a kicsi” (Klára).

A Lupus Albus Osztályon az együttmüködés nemcsak az anya-gyermek, hanem a többi érintett közötti szoros kapcsolatról is szól (az egy későbbi izgalmas kérdés, hogy ez nem feltétlenül érdeke mindenkinek). Többen említették, hogy cél az, hogy a szülő ,,ne érezze idegennek ma- gát” az osztályon, sőt a család szót használva meséltek erröl: „Majdnem, hogy családtagnak tekintenek egy idö után minket. Megtudjuk, hogy mi van a nagy gyerekkel, a nagymamával, hogy állnak a lakásfelújítással” (Enikő). Így látta ezt egy édesanya is: „Ott voltak velem, szurkoltak [...]. Mondhatom azt, hogy családként müködtünk együtt", (Nóra).

2. ábra

\section{Kapcsolat-háromszög}

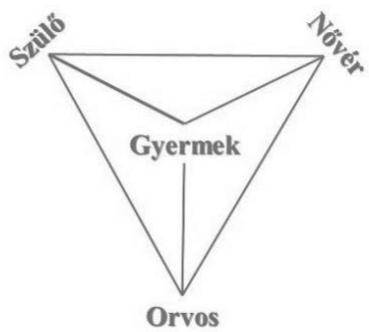

Forrás: saját szerkesztés

Az itt kifejtett kapcsolati hálót a 2. ábrán jelenítem meg, ahol a szereplők elhelyezése is sugallja két észrevételemet. 1) A középpontba valóban a gyerek kerül, akinek felépülése közös célja az érintetteknek. 2) A szülö-gyermek-nővér háromszög érintettjei közelebb állnak egymáshoz, köztük intenzívebb az együttmüködés a hétköznapokban.

\section{Vezetés, alá- és fölérendeltség}

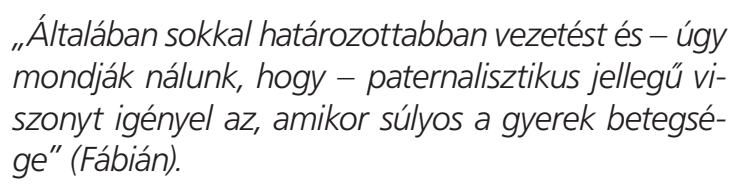

A bevonás szinte elengedhetetlen szükségéből, a tanulási folyamatból, a kapcsolódás körülményeiböl és az érintettek beszámolóiból is kitünik, hogy az együttmüködésben megjelenik egyfajta vezetés és alá-fölérendeltség a kiszolgáltatottság következtében. Tetten érhető a szakirodalom (lsd. Verdes, 2020) orvos-páciens kapcsolat (kommunikáció, döntéshozatal) témaköre, amelyre itt egyfajta ,vezetésként" utalnak.

Ennek van egy szorosabb értelemben vett irányító, feladatokra vonatkozó jelentése: „Időnként örmesternek érzem magam, aki arra figyel, hogy mindenki megcsinált-e mindent: szülők, orvosok, nővérek, orvostanhallgatók, bárki, aki bejön" (Enikő).

A vezetést ugyanakkor, mint a kapcsolat kezelésének módját is említették. Ez felelősségvállalást jelent a dolgozók részéről, amikor például ,,beszélek egy szülővel vagy vezetek egy kapcsolatot” (Mihály). „Az itt elvégzett munkának gyakorlatilag az egyik legnagyobb része, hogy a szülö [...] pszichésen, lelkileg vezetve legyen ebben az egyébként iszonyú nehéz helyzetben" (Fábián). Ez nagyon nehéz helyzetek elé állítja a dolgozókat. „A legnehezebbek azok... Fiatal szülök, elsö gyerek, anyuka meghalt egy kórházban, a gyerek itt nálunk. Ezt az apát végigvezetni..." (Enikö). 
„Van olyan, hogy próbálnak akkor is az egyenrangúságra törekedni [a baba súlyos betegsége esetén a szülök], de össze vannak belül törve és ehhez kell egyfajta vezetés, hogy tudjuk tartani a kapcsolatot egymással. Néha a kettőt [partneri viszony és az, amikor vezetve van] együtt kell játszani, hogy megmaradjon az, hogy érezzék, hogy van beleszólásuk és van lehetöségük érvényesülni, akár módositani is dolgokon, és egyszerre meglegyen az, hogy ugyanakkor vezetve legyenek, mert teljesen össze vannak törve." Fábián szerint ez függ a gyerek állapotától is, de emellett a szülő neveltetésétől és szociális környezetétől is.

A vezetés tehát a napi rutin és a feladatok irányításán túl lelki vezetést, a kapcsolat kezelését is jelenti az együttműködésben. Ebben felbukkan a megértés szerepe, azaz ,a páciens jelentésvilágának figyelembevetéle”, aminek fontosságáról Málovics (2009) is ír. Egy általános elv (ideáltipikus informáltság) helyett az igények felismerése, és az ezekhez való alkalmazkodás az, ami valódi páciensközpontúságot, nem csupán páciensközpontú kommunikációt jelent a gyakorlatban (de Haes, 2006).

\section{Közös cél}

"Egy érdekünk van és célunk, hogy ez a bébi úgy megússza ezt a jelen állapotot, hogy a lehető legjobbat hozzuk ki belöle" (Olga).

A gyerek érdekei állnak a középpontban (1sd. 2. ábra), és ezt megerősítették a nővérek, akik ezért tanítják, felügyelik a szülőt, sőt akár az orvossal szemben is képviselik a kicsi érdekeit: „A gyerek irányít. Mi vagyunk az ö szócsöve. Mi látjuk azt, hogy öneki most ez nem jó. Hiába van az kiírva, hogy ez meg ez [például táplálás kapcsán]" (Olga).

Az orvosok szintén ezen a véleményen vannak. ,Gyakorlatilag mindenkinek azt kell leginkább szem elött tartani, hogy a kisbabának minél könnyebb és gyorsabb gyógyulása legyen" (Fábián).

Az édesanyák megélése is hasonló. „A legfontosabb mindenkinek az, hogy a gyerek meggyógyuljon vagy legalábbis, ha máshová kell mennie, akkor úgy menjen tovább, hogy nyugodt szivvel adhassák át egy másik osztálynak" (Ildikó).

Az osztály dolgozói arra törekednek, hogy az adott nehéz helyzetből a lehető legjobbat hozzák ki, valamint a folyamatba (pl. feladatok ellátásába) bevonják a szülőket is, és mindezek során a gyerek gyógyulása mindannyiuk érdeke.

\section{7. Érdekellentétek}

\section{"Nehéz így dolgozni, hogy ott van az édesanya" (Anna).}

„Vigyázni kell az adatokra.” - folytatja a nővér. Az egyik probléma, hogy a titoktartás nehézkessé válhat egy ilyen kis helyen, mint az osztályon található kórtermek.

\section{Érdekellentétek a kapcsolatban}

3. ábra

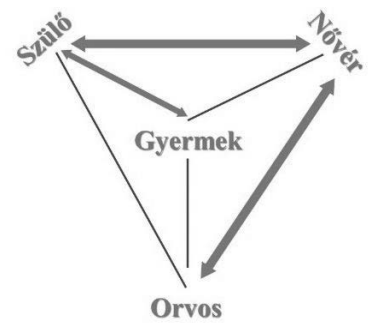

Forrás: saját szerkesztés

Az előzőt kiegészítve a 3. ábrán megjelenítem azt a három érdekellentétet magában rejtő kapcsolatot, amelyeket itt kifejtek.

A nővérek és édesanyák között a közös cél mellett jelen van az érdekellentét is, például a látogatási rendre és időre vonatkozóan, ami sarkalatos pontja az együttmüködésnek és egyben konfliktusforrás is. ,A szülőknek az [az érdeke], hogy bárki bejöhessen." Bármilyen állapotban van a kicsi, ők szeretnék megosztani az élményüket a családtagokkal. Ezzel szemben viszont „,Mi a zsúfoltság miatt annyira nem. Mi növérek inkább azt szeretnénk, ha ez le lenne minimalizálva. Mi látogatást is kevesebbet szeretnénk" (Bori).

Egy másik ellentét a tájékoztatásban fedezhető fel. „Estefelé, amikor [...] nehezebben kommunikál az ember fáradtan, akkor nem olyan jó, hogy akkor jön be és akkor akarja elölről átbeszélni az egészet” (Júlia). „,Nagyon sokszor a szülö várja, hogy legyen egy olyan felelösséget vállaló személy, akihez ő kapcsolódhat. Ezen az osztályon mi nem tudjuk megcsinálni, mert ez egy intenzív ellátó egység. [...] itt egy csapat vállal felelösséget a gyermekért" (Mihály).

Még a nővér-édesanya kapcsolatban a bevonás során is jelenik meg ellentét. Sokszor a szülő akadályozza a munkát, például amikor ,Nem érdekli, hogy te a másik, esetleg súlyosabb gyereket látod el, azonnal ugorj oda és csak az övé a fontos” (Cecília). „Amikor eröszakos, hogy „ezt én akarom csinálni, én ezt jobban tudom", majd utána öszszepisilteti az egész ágyat, és akkor még azt is húzhatod, meg át is öltöztetheted, akkor az inkább bosszantó, mint segitség" (Cecília).

Ezekben a kapcsolatokban, az érzelmek szintjén felmerül még, hogy „Mindenki nagyon zordnak és nagyon keménynek mutatja magát" (Enikő). A nővér arra utal, hogy a nővérek szorosabban kötődnek a gyerekhez, mint a felnőttekhez, sőt velük sokszor nem is szívesen dolgoznak együtt. Orvos a szülőkröl: „Vannak, akik túl bizalmaskodók, és úgy próbálják a helyzetet kezelni...” (Júlia). „Én már megtanultam távol tartani őket magamtól. Mert, ha én fölvenném az ö bajukat, akkor én nem tudnám ezt $[\mathrm{x}]$ éve csinálni" (Olga).

Az együttműködésben kevésbé jelentős, de sokszor felmerülő érdekellentét anya és gyermeke között is előfordul. (Ez a tanulás témaköre alapján rövidebb távon feloldható.) A kötődés kialakításának nehézségei miatt ebben a helyzetben érthető, hogy az édesanya legtöbbször szeretne 
fizikai kapcsolatot létesíteni a kicsivel, hiszen sokszor a simogatáson kívül nem tud mást tenni érte. A nővérek, orvosok viszont a gyerek nyugalmának érdekében ezt nem mindig helyeslik, mert ez a babát ,felidegesiti”.

Az orvosok és nővérek közötti érdekellentét abban jelenik meg, hogy az orvosok a szülők és a gyerekek érdekeit képviselve próbálják a rendszert alakítani. Ez magában foglalja a látogatási időnek, de a nővérek hozzáállásának alakítását is.

Az érdekellentétek kapcsán megjegyzem, hogy a megkérdezett édesanyáknak nem volt panaszuk ezekre, inkább azt fejezték ki, hogy elégedettek az osztállyal. (Ez igazolja az elöfeltevést, hogy akikkel én kerülök kapcsolatba a kutatás során, ők jellemzően pozitív véleménnyel lesznek.) ,Szerintem ez a legfontosabb, hogy az anya és a babóca így együtt legyenek. És ezt az osztály biztositja számukra...” (Helga). Persze ez nem általánosítható minden, az osztállyal kapcsolatba kerülő hozzátartozóra, de egy nővér is erre utal: „Ök [a szülők] nem érzékelnek ebből a belső feszültségből semmit. Szóval valamit jól csinálunk" (Dóra).

Hiába tehát az elégedettség, ennek a belső feszültségnek a részbeni feloldásához segítséget adhat a mélyebb megértés, mert az osztály életét meghatározó együttmüködés szereplői között jelen vannak az eltérő érdekek. A szülők és nővérek között erre a látogatási idő, a bevonás és az érzelmi kötődés mértékével kapcsolatban derült fény. A szülő és babája viszonyában is lemondásokkal jár a gondoskodás, az orvosok pedig a nővérekkel szemben képviselik olykor a szülők és kicsik érdekeit.

\section{8. Érzelmek}

"Nagyon sok a szeretet, nagyon sok a kézzel fogható érzelem, ami ebben a picike kis közösségben megvan" (Nóra).

Az elbeszélésekben kirajzolódott pár jellemző, gyakori érzés.

Félelem, aggodalom. Az egyik anyuka más koraszülött babák anyukáival való tapasztalatáról mesélt. „, $\mathrm{Na}$ gyon-nagyon félnek a kórháztól, félnek az ismeretlentöl, hogy vajon mire számitsanak, hogy fognak hozzájuk állni, merjenek-e kérdezni” (Nóra). Az osztály dolgozóinak egyike ezt így fogalmazta meg: „...nem nagyon mernek hozzányúlni, mivel egy inkubátorban van, nem tudják, hogy mi a szabály” (Anna).

Tehetetlenség. „Egy szülőnek érzelmileg ez nagyon megterhelö. És egy apának is. Mert ugye ö a családfenntartó, neki az lenne a feladata, hogy osztozzon az örömben, támogassa a feleségét, de itt tehetetlen” (Enikő). Ez az osztály dolgozóinak oldalán is jelen van. „Amit nekem kell tudni feldolgozni leginkább, az a tehetetlenség, mert azzal sokszor szembesül az ember" (Fábián).

Feszültség, düh, önvád. ,Sokszor ez a tehetetlen düh az ápoló személyzeten csattan az apa, meg az anya részéröl is. Ha ezt a dühöt fel tudom oldani, ezt át tudom alakitani, hogy segitsen, hogy elfogadjon, akkor nyert ügyem van.” (Enikő). „,[A szülő] elöször elkeseredett, magát okolja, majd utána dühös. És kibe rúg bele? Hát a nővérbe fog" (Olga). Ezek miatt, illetve a korábban bemutatott érdekellentétek okán a nővérekben is van feszültség. ,, $E z$ egy feszült hely" (Fábián). Ez a rövid mondat a pihenés hiányára, a munka jellegére vonatkozott.

Érezhető, hogy ezek az érzések és idézetek inkább a viselkedések hátteréről mesélnek. Magában az együttmüködésben tetten érhető még az öröm és a hála is. Az egyik anyukával lehetőségem volt úgy beszélgetni, hogy éppen akkor vehette először mellére a kisbabáját. „Engedtek a növérkék például pelenkázni, meg segíteni idézöjelesen, hogy megnyugtathattam a babát, ha sirt. Meg hát most is kivehettem. Most elöször. [...] Most olyan jó érzés. Itt van végre ez a kislány" (Helga). A szülők hálájának egy kifejeződése az a sok fénykép a kisbabák neveivel, dátummal, rövid köszönetekkel, amelyeket kitesznek a falakra (kórtermek mellett, konyhában). Az öröm a nővérekben is jelen van: „Fárasztó, nagyon fárasztó. De jó érzés, amikor anyuka bejön és nevet és hullik a könnye [az édesapa és a tisztába tétel kihívásai okán]” (Enikő).

\section{Gondoskodás, ellenállás, küzdelem}

Az érzelmeken és az összes eddigi válaszon túlmenően az együttmüködés értelmezésem szerint a továbbiakat is jelenti.

Gondoskodást, mert „Segitenek, informálják az embert, megnyugtatják, ha úgy van.” (Helga). „Szoktam mondani: egyszer mutatom [a fürdetést például], utána anya csinálja. „És, ha nem megy?” Itt leszek, segítek” (Enikö).

Jelen van az ellenállás, hiszen „Próbáltunk ebbe az irányba mozogni [külföldi példa a bevonás terén], és az a szülők oldaláról is sokszor ellenállásba... Nem akar annyira involválódni a babának az ápolásában” (Mihály).

Az ellenállás és a körülmények ellenére kitartást, küzdelmet jelent még az együttmüködés. Egy szülő „,nem kötödött semmilyen módon a gyerekéhez. Jött így tisztességböl, ellenséges volt, támadó volt. És azzal, hogy több türelemmel igyekeztünk rávezetni arra, hogy feladatai vannak a babájával, egy máig visszajáró barátunk a kicsi gyerekével” (Mihály). „Ez az osztály egyébként is arról szól, ami itt a tevékenység: egy közös küzdelem. Néha egymással" (Fábián).

$\mathrm{Az}$ interjúk eredményét összegezve elmondhatom, hogy a Lupus Albus Osztályon megvalósuló együttmüködés egyszerre jelent: tájékoztatást és szabályokat; bevonást és feladatokat; egy tanulási folyamatot; kapcsolatot, kötődést; vezetést; közös célt; érdekellentéteket; érzelmek megélését. A beszélgetések elemzése alapján úgy vélem, hogy mindezeket az általam elért érintettek közös megéléseként foghatom fel.

\section{Mit mond minderről a ...? - További módszertanok eredményei}

A következőkben bemutatom az interjún kívül megvalósított módszertanok tapasztalatát. 


\section{Dokumentumelemzés: a tájékoztató füzet}

A hatoldalas színes, fényképekkel ellátott tájékoztató füzet vizsgálatát kiváló lehetőségnek gondolom arra, hogy közelebb kerüljek a megértéshez, hiszen ez a pár oldal az együttműködésről szól, ahogy a szöveg bevezetőjében is olvasható: ,...hogy minél zökkenőmentesebb lehessen az együttmüködésünk...” Az egyik anyuka így hivatkozott rá: „Van egy nagyon jó kis tájékoztatójuk, amiben benne van [...], hogy a közös munka az nem csak az ö részükröl közös munka, hanem a szülökkel együtt is közös" (Ildikó).

A füzet nyolc témaköre, fejezete átfedésben van a fentebb tárgyaltakkal, ugyanis a látogatási rendről, az ápolásról, a szabályokról, a tájékoztatásról és a családról, mint a gyógyulási folyamat kulcsszereplöjéröl van benne szó. Utóbbi fejezet szó szerint is említi ,a szülők partnerként való bevonását", ami a gyógyulást és a korai szülö-gyermek kapcsolat megerösítését szolgálja (pl. az anyatej vagy a kenguruzás eszközével). A füzet gondolatmenetét érzelmekről szóló mondatok keretezik. A megszólítást követő mondat a ,nehéz, aggodalommal teli” helyzet jobbítására vonatkozó reményt fejezi ki. A szöveg utolsó mondata pedig az abban való hitről szól, hogy a „,nyitottság, bizalom és elfogadás segit leküzdeni a félelmeket", és ez is a kicsik „közös gyógyitását” segíti. Látható, hogy ezek összhangban vannak a korábbi értelmezésekkel is.

Úgy gondolom, hogy a füzet szerkezete, a képek és a szöveg aránya egyensúlyt teremt az információk és az osztályhoz való képi, hangulati kapcsolódás között. A képek mindegyikén egy-egy baba van a középpontban, ami megerősíti az érdekek kapcsán tárgyaltakat. Ötből három képen pedig valamilyen formában megjelenik a velük való kapcsolat: egy érintés, öltöztetés, egy nővér.

A szöveg és maguk a képek is őszinteséget és átláthatóságot, illetve alaposságot sugallnak. A mondatok elismerik az osztály korlátait (pl. zsúfoltság), törekvésekről beszélnek és határozott kérésekröl. A három, az osztály terét megjelenítő kép szintén őszinte: bár nem zord hangulatot láttatva, de a képeken ott vannak az inkubátorok, a babát körülvevő orvosi gépek, csövek.

\section{Állatmetafora: a tudatalatti}

Erös önkritika mellett fogalmazhatok csak úgy, hogy a tudatalatti. Ezt az asszociatív technikát érdekesség és kiegészítésképpen mutatom be. A 4. ábrán összegyüjtöttem a beszélgetések végén válaszként elhangzott állatokat.

4. ábra

\section{Állatmetaforák}

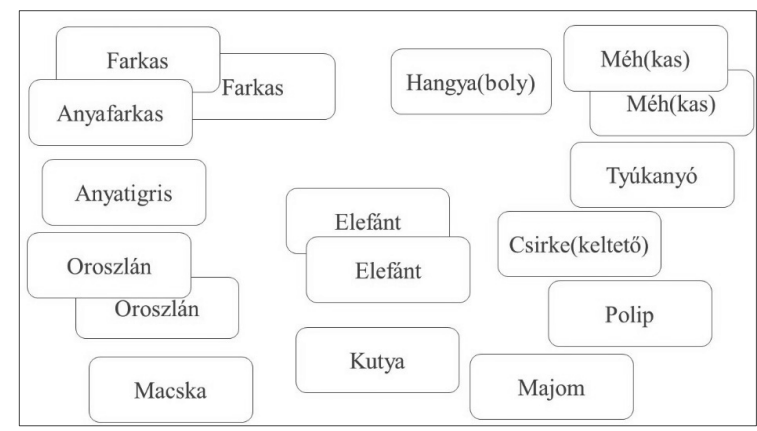

Forrás: saját szerkesztés
Ez a módszertan megerősítette az eddig tárgyaltak érvényességét, de új gondolatokat is adott az érintetteknek. (Például a méhkas említésével előkerült a délelőtt megterhelö, zsúfolt programja, amikor megérkeznek az orvostanhallgatók.) Az állat kapcsán mindig elhangzott pár gondolat (jellemző) arról, hogy az illető számára miért az testesíti meg az osztályt legjobban. A szerepkörök alapján nem tapasztaltam markánsabb eltérést, csoportosulást. A nővérek esetében kiemelhető, hogy inkább a nyüzsgéssel, jövés-menéssel jellemezhető állatok kerültek előtérbe: hangyaboly, méhkas, csirkekeltető, polip. Az alábbiakban viszont a jellemzők tömör gyüjteményét nem állatokhoz vagy interjúalanyokhoz kötve, hanem hasonlóságuk mentén csoportosítottam, azt keresve, hogy milyen is ez az állat, azaz ez az osztály:

• gondoskodó (,,gondoskodik”, ,táplálás”, ,,szeretet”, „védelmez"),

• szerethetö (,,cuki”, „tud dorombolni”, ,barátságosak", ,jókedv"),

• közösségben él (,,falka”, ,,állatkert”),

• fegyelmezett (,,egy agy, sok kéz”, ,, szabályok”, ,fo"nök”, ,,szigor", ,fegyelem”, ,,rend", ,,stabil”),

• méltóságteljes (,okos”, „nagy”, „megnyugtató”, „,békés”, ,kicsit lomha”, ,nyugodt”, „megbizható”, „,autonóm”, , stabil") és

• kitartó (,,izeg-mozog”, ,,pörög”, ,,terhelhetö”, ,,soha nem adom fel", ,,küzdelem").

A csoportosítás már az én munkám, és megerősített abban, hogy a módszer adta felismerések átfedésben vannak az előzőekkel, árnyalják azokat. Például a kapcsolat fontosságát sugallják számomra a „gondoskodó” és „szerethetö" csoportok jellemzői, vagy a vezetés témakörével tudom párhuzamba állítani „állatunk” fegyelmezett és méltóságteljes tulajdonságait.

Izgalmasabb és a módszer lehetőségeit is jobban kihasználó eszköz lehet az, ha összekötjük állatmetaforákat az asszociáció nyújtotta megértés lehetőségével. Munkám során itt tetten érhető a legtisztábban bevonódásom az értelmezésbe, hiszen a következőkben a metafora (állatok) a kutatás alanyától, míg az asszociáció, értelmezés már a kutatótól, azaz tőlem származik.

- Az állatok közül párnál az a jellemzőbb, hogy nagy csoportban élnek (pl. méh, hangya), míg másoknál nem (pl. kutya, macska).

-Vannak kifejezetten mozgást, dinamizmust sejtető állatok (pl. méhek, farkasok), illetve lassúbb, számomra nyugalmat megjelenítőek (pl. elefánt, polip).

- Nagy az eltérés még az állatok méretében is (hangyától az elefántig).

Ezek a megfigyelések azt sugallják nekem, hogy sokszínü, eltérő vélekedések is jelen vannak az osztályon. Ezek nem feltétlenül ellentéteket jelentenek, esetleg vágyakat valamire, illetve eltérő megítéléseket helyzetekről (pl. a méretből kiindulva eltérő megélést az osztály szerepéről a tágabb rendszerben: a kórházon belül vagy az egészségügyben). 


\section{Térelemzés: az osztály fizikai környezete}

„Félve mentem be, hogy milyen lesz a kisbabám, milyen a környezet. Ugyanakkor izgatott, mert kívülröl erröl a kórházról szerintem senki nem gondolná, hogy egy kórház" (Klára). Az interjúk során nem volt a térre vonatkozó kérdés, de így is elhangzottak idevágó gondolatok. Az 5. ábra segít az Olvasónak elképzelni a fizikai közeget, és ennek segítségével rövid, elnagyolt leírását adom a térnek.

5. ábra

Az osztály elrendezésének vázlata

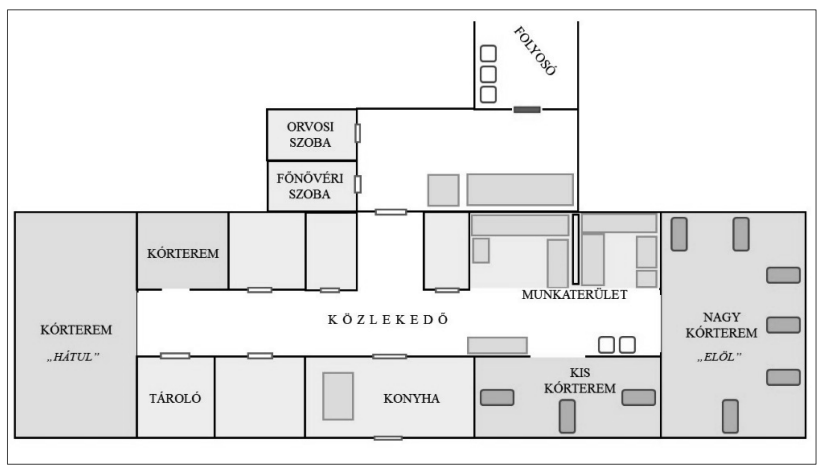

Forrás: saját szerkesztés

A folyosóról egy olyan ajtón keresztül lehet bejutni az osztályra, ami kártyával vagy - az általam munkaterületnek nevezett részen található - gombbal nyitható. Belépve egy előtér található egy szekrénnyel a kabátoknak, tájékoztató anyagokkal a falon. Innen nyílik az orvosi és főnővéri szoba, illetve egy szekrénnyel ,szegélyezett” újabb előtér közvetlenül a belső folyosóhoz (ahogy én nevezem: közlekedőhöz) kapcsolódva. Az ábrán baloldalon (,hátul”) található az a két kórterem, ahol a jobb állapotban lévő babák vannak. Itt különböző tároló szobák vannak még. A jobb oldalon, azaz „elől” az akkut ellátás, a súlyosabb állapotban lévő gyerekeknek helyet adó kórtermek találhatóak. Az ábra kidolgozottsága árulkodik arról, hogy én ezen az oldalon mozogtam jellemzően. A kórtermekbe nem léptem be (csak két interjú során), de mindegyikbe be lehet látni a közlekedőről, ezeknek nincs becsukva az ajtaja.

Ottlétem alatt az ábrán látható elrendezésben álltak az inkubátorok (téglalapok). ,Mindegyik mellett ott van a szék, ami az anyának a helye gyakorlatilag" (Anna) és az orvosi eszközök, gépek. A két székkel (kis négyzetek) szemben látható a nővérek, orvosok egyik fő munkavégzési helye (munkaterület): jobbra az adminisztráció (számítógépek, fénymásoló), balra pedig az ellátást elökészítő munka (pl. gyógyszerelés) terepe. A közlekedő konyha környéki részén, a falakon sok fénykép van felrakva a babák neveivel, a szülők háláját kifejező rövid üzenetekkel.

A fizikai közeggel kapcsolatban az osztály részéről egyértelmü elégedetlenség van, elsősorban a hely szűkössége miatt. Saját megfigyeléseimből a következőket emelem ki.

- Amikor elöször jutottam be az osztályra, ezeket jegyeztem fel a munkaterülettel szemben található széken ülve: ,szük, egy légtér”.
- A reggeli átadásakor a kis kórterembe csak két személy fért be, a dolgozók csoportja a közlekedőre szorulva hallgatta a párbeszédet.

- A napi jövés-menésben sokszor ,,beszorulva éreztem magam" ott a székben.

Az egyik nővér a téma kapcsán idegessé válva így beszél a szükösségről: „Ö is azért nem tudja kipakolni, mert nem fér oda. Közben lerakja valahova, ahova te mennél gyógyszerelni, de ott nem férsz el. Közben vinnéd a valamit, de oda se férsz, mert ott meg van egy koszos inkubátor éppen..." (Dóra).

A tájékoztató füzetben a látogatási rend kapcsán felsorolt hét fontos szabály közül háromban szerepel a „zsúfoltság” szó. Ez az együttmüködésre közvetlenül hatással van, erre utal a következő idézet. „A növérek leggyakoribb indoka, hogy miért ne legyen itt a szülö, az az, hogy [nővéreket idézve] ,nem férek hozzá a gyerekhez. Folyton kerülgetnem kell, mert egyszerüen ott a sarokban nem tudok odaférni az inkubátorhoz, mert ott áll a gép, a kisszekrény és még a szülö székét is kerülgessem folyton" (Lajos).

Ettől a közvetlenül fizikai problémától kicsit eltávolodva megjelenik az igény arra is, hogy a tér valamiképpen ellensúlyozza az érintettek nehéz helyzetét, hiszen a kapcsolatokra is komoly hatással van. (Lsd. a korábban említett titoktartás az egy légtérben lévő betegek és hozzátartozóik kapcsán.) Egy orvos szerint más intézmények azért járnak előrébb az orvos-szülő kapcsolat kezelésében, mert több mindent tudnak biztosítani számukra (pl. szállás, idő a gyerekkel) és a térhez kapcsolódóan ,, Sokkal kényelmesebb, intimebb körülmények között tudják szoptatni a gyereket, így a szülö-gyerek kapcsolat van szorosabbra füzve” (Fábián).

Magát a kommunikációt is megnehezíti ez a közeg az orvosok számára (már az első találkozáskor): „,Leülünk, próbálunk keresni ebben a nagyon nehéz építészeti környezetben valami nyugodt sarkot" (Mihály).

Belátható tehát, hogy a tér az együttmüködés olyan fontos elemeire van hatással, mint például az érdekellentétek (látogatás, titoktartás), érzelmek (félelem), kapcsolatok (intimitás), orvos-hozzátartozó kommunikáció.

Az eddig tárgyalt szempontokhoz (bevonás, tanulás, érdekek) hozzátartozik még egy, a terekkel kapcsolatos meglátásom. A kihívások mellet ez a fizikai környezet egyfajta átláthatóságot, nyíltságot közvetít például azzal, hogy egy légtérben zajlik a nővérek háttérmunkája, közlekedése és a babák ápolása. A szülők és én magam is láthattam, ahogy zajlik a mindennapi munka. Lehet, hogy intimebb, a titoktartást, mindenki nyugalmát szolgáló, elkülönített helyen is ápolhatná a kapcsolatot az édesanya a gyermekével, de ezzel talán valami mást elveszítene mindegyik érintett. A következő idézetek megmagyarázzák, hogy mire gondolok. ,Úgy éli meg gyakran [a nővér], hogy a szülö ellenörzi az ö munkáját és kötekedni akar. Nem látja meg azokat a pillanatokat, amikor a szülö látja, hogy mennyi munka van az ö gyerekével és értékelni tudja azt, hogy elvégezzük ezt a sok munkát” (Lajos). Ezt egy édesanya is megerősíti: „,Nagyon tetszett az, hogy öket nem csak betegként, hanem gyerekként is kezelik..." 
(Ildikó). Szó van itt kapcsolatról, bizalomról és érdekek találkozásáról. Egy olyan fontos dolog szolgálatában áll a tér, mint a közös (szervezeti) tanulás, bár ez nem tudatos szándékkal és nem kényelmes módon történik.

Ezeken túl az osztályon tartózkodva vagy az ábrára ránézve a közeg zártságot sugall. Ez egy elkülönült világ, akár egy védelmező burok fizikailag vagy éppen lelkileg (ahol könnyebb ,letenni a munkát”, ami sokaknak fontos is itt).

\section{Résztvevő megfigyelés: a személyes tapasztalat}

Az osztályon sokszor „csak üldögéltem” és jegyzeteket készítettem. Ez nem lehetett a közegtől független, idővel megismertek. Előfordult, hogy odajöttek hozzám megosztani pár gondolatot (egy állatmetaforát, pár panaszt). Nem éreztem, hogy másképpen viselkednének a jelenlétemben, nem tünt úgy, hogy zavarnám őket. A személyes jelenlét sokat adott ahhoz, hogy megértsem, átérezzem ennek a helynek a hangulatát, ahol közösen gondolkodtunk az együttműködésről. A kiemelt gócpontok érvényességét erősítette meg ez a tapasztalat (például egy édesanyát látva a babája mellett, egy nővért látva előkészület közben; 1sd. kapcsolat és gondoskodás). A terjedelembeli korlátok miatt csak egy rövid példát említek.

Egyik délelött tanúja voltam annak, ahogy a beengedésre várakoztak az anyukák. Egyiküknél ott volt a bevonás részét képező csomag (pelenka stb.), és szóba elegyedtek egymással. Ez két új szempontot vetett fel, amelyekre az interjúk során is hallhattam utalást. Egyrészről, hogy az együttműködés szempontjából a szülők közötti viszonynak vajon milyen jelentősége van, vagy lehetne. Másrészről, hogy a tér ezt mennyire nem szolgálja: a várakozást, a közösség kialakulását.

Az előbbi módszertanok megerősítették, és egyben árnyaltabban láttatták azokat a fontos elemeket, amelyeket az együttmüködés helyi jelentésének megértése eredményeképpen kiemeltem. Felmerült új gondolatként például az öszinteség és a zártság, illetve annak a kapcsolatnak a fontossága, ahogy az együttműködés élettelen eszközei viszonyulnak a tájékoztatáshoz vagy a tanuláshoz: megerősítően (a füzet), de feszültséget, ellentéteket hordozóan is (a tér).

\section{Mit kezdhetünk mindezzel? - Megértés a fejlesztés szolgálatában}

\section{"Igazából ez egy olyan világ, amit át kell élni" (Helga).}

Hogyan segítheti a megértés az érintettek munkáját? Long (2001, pp. 106-107) az együttműködő kultúra kialakítása érdekében három szempont teljesítését javasolja: 1) tisztán lefektetett feladatok és szerepek, 2) képesség a tapasztalat és cselekvés általi tanulásra, valamint a 3) képesség a meghallgató és érzelmileg megtartó munkakörnyezet kialakítására és fejlesztésére. Ezzel a kutatással - annak folyamatával és tartalmával - ezek kialakításához járulhatok hozzá. Fontos, hogy ez nemcsak egy írásos összefoglaló átadását jelenti, hanem közös folyamatot, aminek kiindulópontja a megtapasztaltak visszajelzése és az azzal való közös munka.

Ezt a munkát egy ilyen megismerés szolgálhatja igazán. „A külső tanácsadó is csak akkor tud a szervezettel jó kapcsolatba kerülve tényleges segítséget nyújtani, ha [...] megértésre törekszik. Ez azonban nem könnyü" (Gelei, 2006, p. 92). S arra, hogy ez a megértés valóban nem könynyü, a „terepen” is utaltak (a fejezet mottójához hasonlóan): „Ezt csak az tudja megérteni, aki hosszú-hosszú ideje gyerekekkel foglalkozik, és nem is akar mással" (Dóra). ,,[Aki nem csinálja] az nem érti meg, milyen krónikusan fáradtnak lenni” (Enikő).

Az itt említett célokat (lsd. Long és Gelei) hogyan szolgálta és szolgálhatja az édesanyák bevonása? Mit nyertem ezzel én, mit nyerhet ezzel minden érintett? Megvalósult eseteket vizsgálva írtam (Verdes, 2020) arról, hogy a „külső” érintettek bevonása viszonylag ritkán valósul meg fejlesztési folyamatokban. Itt annak fontosságát hangsúlyozom, hogy az osztály dolgozói és a hozzátartozók egy közös folyamatban vegyenek részt. Nem külön-külön érdemes tehát kutatni vagy fejleszteni az érintetteket. Egy ilyen osztályon, ahol az együttmüködés ennyire „kézzel fogható”, enynyire kulcsfontosságú és közös érdek, elválaszthatatlannak tartom ezeket az alrendszereket (French \& Bell, 1995).

A hatékony és biztonságos páciensellátás érdekében Ratnapalan és Uleryk (2014) az egészségügyben központi szükségletnek tartják a folyamatos tanulást, a rendszerek (szerepek, felelősségi körök) összekapcsolódó, dinamikus együttmüködése (információátadás, kapcsolattartás) közepette. A Lupus Albus Osztályon az együttműködésnek része a tanulás. Egy orvos szerint például fontos, hogy a nővérek lássák azt, hogy egy szülö a közös munka során tudja értékelni az ő gondoskodásukat (lsd. a térről szóló fejezet). Az ilyen jellegű reflexiók tapasztalati tanulásba való beépítése a szervezetfejlesztés alapköve (Gelei, 2020). A szervezeti szintű tanulás (Senge, 1998) és a változás, illetve az ezeket támogató szervezetfejlesztői diagnózis vagy folyamat ezen az osztályon nem - és szerintem más hasonló osztályokon sem - valósulhat meg a szülők bevonása nélkül. Ezt a felismerést segítette, és egy ilyen munkának az elindítását könnyítheti meg ez a kutatás.

A megértésből fakadóan általam megfogalmazott felismeréseknek, gondolatoknak már „csak” a visszajelzése is olyan erővel bírhat, amiröl az interpretatív közelítés kapcsán esik szó: segíthet fellazitani a berögzült mintákat azáltal, hogy ezeknek a közös folyamatban való létrehozására világít rá (Gelei, 2006 alapján). Ebben pedig vitathatatlanul a szülők is részt vesznek. Fontos elem itt például az érdekellentétek kérdéskörének közös megvizsgálása, ami a feloldásukat is lehetővé teheti. Ehhez kapcsolódóan fontos Goh és társai (2013) tapasztalata, miszerint ott, ahol a csapatok között hatékonyabb a kommunikáció, ahol a pácienseket helyezik a középpontba, és a hibákat nem elkendőzni próbálják, hanem tanulni szeretnének belölük, ott kevesebb hiba történik, a nővérek elégedettebbek a munkájukkal és kevesebb a kiégés. Ez a megértő közelítés lehetővé teszi, hogy az érintettek egymást és a közös folyamatukat értsék meg (pl. hibák, kommunikációs nehézségek gyökereit). 
Munkám tapasztalatát megosztva az érintettekkel, velük közösen olyan mélyebb, alaposabb fejlesztési program dolgozható ki, amely konkrét kihívások kezelésében ad támogatást (pl. a rossz hírek közlésének kihívásait vagy egy pszichológus szükségességét többen említették). Kiindulópont lehet a PAF Alapítvány két képzése: „Változáskezelés az egészségügyben” és „Öszinteség vészhelyzetben” (PAF Közhasznú Alapítvány, 2020). Mindenesetre bármilyen fejlesztői beavatkozást az érintetteket a közegükből nem kiemelve érdemes megvalósítani. Cocowitch és társai (2013) is hangsúlyozzák ezt, azaz a rendszerszemléletü közelítést, olyan tanulási környezet kialakítását, ahol megvalósulhat a tapasztalati tanulás, méghozzá az adott szervezetre testre szabottan, alkalmazkodva annak környezetéhez, értékeihez és hitrendszeréhez. A szülők nézőpontjának megismerése pedig, a bevonásnak köszönhetően a dolgozók képességeinek (pl. kommunikáció, empátia) célzott fejlesztéséhez járulhat hozzá, ahogy ezt Tempfer és Nowak (2011) véleményében is idéztem korábban (Verdes, 2020).

Bármilyen képzés, fejlesztés megvalósulását segítettem már most azzal, hogy könnyebbé válhat a belépés ebbe a szervezetbe, és a kialakult bizalom a közös munka elfogadottságát támogatja. Saját tapasztalatai alapján szintén ennek fontosságáról írt Stoelwinder és Clayton (1978).

Összességében tehát a megvalósult kutatás az együttmüködés fontos elemeinek felismerésével, azok kapcsolatának (rendszerszemléletű) megértésével a szervezeti tanulás alapját képezheti. Munkám eredményeinek ismertetése az érintettekkel, és az erről való közös gondolkodás belátásokhoz és egy szervezetfejlesztési folyamat megalapozásához járulhat hozzá. A megértés fontosságát hangsúlyozó megközelítés és a kutatás tapasztalatai pedig segítséget és támpontokat adnak az egészségügyben, kórházakban később kutató, fejlesztő szakemberek céljainak tökéletesítéséhez.

\section{A kutatás értékelése, korlátok}

Eredményeim, azaz megértésem alaposságát segíthette volna több nővér és szülő megszólítása. Az édesapák kutatásba való bevonásának a rendelkezésre álló időn kívül nem tapasztaltam más akadályát. Ök is részét képezik az együttmüködésnek, de az ő hangjuk hiánya a tanulmányban feltételezésem szerint nem az osztály müködésének leképezése.

Etikai okokból (felismerhetőség elkerülése) nem emeltem ki külön egy-egy szerep tapasztalatait (pl. főnővér, osztályvezető). Ezzel vállaltam, hogy szerepükből adódó befolyásukat nem vizsgálom. Ez, illetve az osztály körülményeinek teljes körű ismertetésének hiánya nem segíti az Olvasó megértését és a kutatás bemutatásának alaposságát.

\section{Megbízhatóság, érvényesség, általánosíthatóság}

Kvalitatív kutatásomat három fontos szempont alapján értékelem Mason (2005) gondolatait mérlegelve.

A megbizhatóság érdekében igyekeztem a kutatás elejétől tudatosan kezelni szerepemet, módszereimet és ezeket a megvalósult kutatási folyamattal együtt átláthatóan bemutatni az Olvasónak. Az adatgenerálás érdekében megválasztott módszerek céljaim elérésére, kutatási kérdéseim megválaszolására alkalmasnak bizonyultak. A kivitelezés, majd bemutatás során törekedtem az alaposságra és pontosságra. Szót ejtettem az adatfeldolgozásról, valamint a bemutatás során az elemzés, értelmezés követhetősége és alátámasztása érdekében sok idézetet használtam.

Az érvényesség érdekében megvizsgáltam, hogy a módszertan valóban annak megismerésére irányul-e, aminek megértését célul tüztem ki (az együttmüködés). A különböző eszközök és érintettek bevonása lehetővé tette, hogy meggyőződjek arról, hogy a levont következtetések nem csupán egyik vagy másik módszer vagy csoport hangját igazolják (trianguláció). Valóban a közös jelentés felé közelítettem (adatgenerálás érvényessége). Nem gondolom, hogy a bemutatott értelmezés lenne az egyetlen helyes út, de saját következtetésem és meggyőződésem logikáját igyekeztem (idézetekkel alátámasztva) átláthatóan az Olvasó elé tárni (értelmezés érvényessége).

Az általánosithatóság kapcsán céljaimhoz igazodva az eddigiek alapján állítom, hogy eredményeimet a Lupus Albus Osztályra vonatkozóan tartom érvényesnek. Ezen túlmenően a tapasztalatomat (a helyi megértést célul kitűző közelítés fontosságáról, a folyamat kihívásairól), a felhasználásra vonatkozó gondolataimat megfontolandónak tartom más egészségügyben végzett bármilyen kutatás vagy fejlesztés szempontjából. Elismerve azt, hogy az a megközelítésről, a folyamatról és nem a konkrét jelenségekről és jelentésekről szólhat elsősorban.

\section{Összefoglalás}

Tanulmányomban olyan kérdésekre kerestem a választ, amelyek megfogalmazásához a saját élmények és az egészségügyhöz kapcsolódó szervezetfejlesztések kihívásokkal teli világának megismerése adta a motivációt. A szakirodalom áttekintése után (Verdes, 2020) egy interpretatív (kvalitatív) kutatást megvalósítva választ adtam arra, hogy mit jelent az együttmüködés egy magyarországi újszülött intenzív osztályon a dolgozók és a szülők számára, valamint ennek megértése hogyan szolgálhatja a fejlesztést. Az interjúk (orvosokkal, nővérekkel és édesanyákkal), egy tájékoztató füzet és a tér elemzése, valamint a résztvevő megfigyelések tapasztalata alapján a következőkre jutottam.

A Lupus Albus Osztályon az együttmüködés kulcsfontosságú tényezője a mindennapoknak. 1) Az orvosok, nővérek és szülők számára ez elsők között tájékoztatást, a szabályokhoz való alkalmazkodást jelent. 2) Az együttmüködés nagyon hangsúlyos részét képezi a szülők bevonása (az információmegosztáson túl) a kicsik körüli feladatok ellátásába. 3) Ezekhez a feladatokhoz azonban a szülönek „fel kell nőnie”, ami egy tanulási folyamat. Nemcsak a hozzátartozóknak, hanem a dolgozóknak is. 4) Az együttmüködés kapcsolatokat, azok építését jelenti ezen az osztályon, elsősorban a gyermek és szülei között. 5) Ebben pedig felelősségteljes, és sokszor irányító sze- 
repet vállalnak a dolgozók a szülők vezetése révén. 6) Az együttmüködés közös célt szolgál: a baba gyógyulását, nehéz helyzetének enyhítését. 7) Ennek ellenére azonban az érdekellentétek is meghatározó alkotóelemként vannak jelen (pl. a nővérek és szülők között a látogatási idő kapcsán). 8) Végül, de nem utolsó sorban az együttmüködés érzelmek megélését is jelenti. Mindezeknek pedig van egy, a szervezeti kultúrát alakító változási folyamatba való beágyazottsága.

Az interpretatív közelítésben megvalósított kvalitatív kutatás egy mély megértést szolgált. Ez a megértés pedig a szervezeti kultúra - benne főszerepben az együttmüködéssel - tudatosításához és alakításához járulhat hozzá.

A hozzátartozók bevonása a kutatásba pedig nagymértékben hozzájárult ahhoz, hogy nem csupán a tényleg helyi, valós jelentések megismerése jöjjön létre, de valóban a közös értelmezésről írhassak. Annak megértése, hogy mit is jelent az együttmüködés és hogyan valósul meg éppen, a szervezeti tanulás alapkövét képezi. Az osztályon az erre vonatkozó igény felmerült ugyan, de a döntés az érintettek kezében van arra vonatkozóan, hogy az eredmények visszajelzésén túl hogyan képzelik el az ezzel való közös munkát. Bárhogy is legyen, a kutatás eredményeképpen kirajzolódnak azok a területek, ahol a belső, valóban jelen lévő igények (pl. kultúra, változás, kapcsolatok terén) és a fejlesztések eszköztára találkozhatnak (pl. PAF Alapítvány tevékenysége).

A felvázolt kutatói megközelítés, a kvalitatív kutatás megvalósítására vonatkozó saját tanulási folyamatom tanulságként szolgál bárki számára, aki kutatóként vagy fejlesztőként hasonló szándékkal közelít az egészségügy egy szervezetéhez. A megértés célja számomra az általános fogalmak mellett (vagy inkább helyett) a helyi, közös jelentés megismerése volt. Meggyőződésem, hogy ez szolgálhatja igazán a különbözö jelenségekkel, témákkal, adott esetben nehézségekkel való jobbító szándékú közös munkát. A kivitelezés módjára, eszköztárára vonatkozóan ez a kutatás nem adhat általános receptet, de példát és ötletet igen. Hangsúlyozza annak fontosságát, hogy azok bevonásával és részvételével érdemes dolgozni, akik szintén hozzájárulnak a helyi jelentés létrehozásához, esetünkben például a szülők az együttmüködés megvalósításához. Ez bármilyen szervezetben értékes lehet, ahol az együttmüködés hosszabb kapcsolatot jelent külső érintettekkel (ügyfelekkel), illetve közös feladatokkal jár. Tekinthetünk ilyen szemmel például az oktatásra is, ahol a diákok alkotnak egy hasonló alrendszert, és ahol az együttműködés és a fejlesztés - véleményem szerint - hasonló megközelítéssel, bevonással lehet eredményes. A kutatás tanulságai alapján profitorientált szervezetek esetében is fontosnak gondolom, hogy a közös cél és szándék megléte ellenére tere legyen az érdekellentétek feltárásának, azaz konfliktusok, a belső megértések és értelmezések különbözőségének vizsgálatának. Ezek tisztán látása önmagában segíthet az azokhoz való viszony formálásában, a valódi megértés a tanulás és fejlődés záloga lehet (a szervezet speciális tevékenységétől függetlenül).

Végül, de nem utolsó sorban egy ilyen megismerést célul kitűző kutatás azt szolgálja, hogy megérthessük, mi zajlik egy kórházi osztályon: statisztikák, költségvetések, szabályok és struktúrák, vagy a felszínre bukkanó érzelmek mögött - a szervezetet alkotó emberekkel. Véleményem szerint ez az, ami lehetővé teszi, hogy saját eszközeinkkel (kutatóként, fejlesztő szakemberekként) segítsünk azoknak, akik mások segítésének szentelik az életüket. Így áll tehát a megértés az együttmüködés és annak fejlesztésének szolgálatába.

\section{Jegyzetek}

${ }^{1}$ Az ötletet egy interjúalanyom adta: „Romulusz és Rémusz meghalt volna, ha az anyafarkas nem segít rajtuk. Ugyanez a helyzet itt is: ha ez az osztály nincs, akkor ezek a babák nagy valószínűséggel nem élik túl az első napokat."

\section{Interjúalanyok listája:}

Az itt szereplő nevek álnevek az ABC sorrendjét követve. (A kutatás során részletes feljegyzés készült az interjúk, megfigyelések idejéről, időtartamáról, helyszínéről, amit itt a terjedelmi korlátok miatt részleteiben nem közlök.)

\begin{tabular}{|c|c|c|c|c|}
\hline Orvos & Nővér & Édesanya & $\begin{array}{c}\text { Időtartam } \\
\text { (perc) }\end{array}$ & Helyszín \\
\hline Anna & & & 20 & Medikus öltöző \\
\hline & Bori & & 25 & Főnővéri szoba \\
\hline & $\begin{array}{c}\text { Cecília, } \\
\text { Dóra }\end{array}$ & & 30 & Konyha \\
\hline & Enikő & & 235 & Főnővéri szoba \\
\hline Fábián & & & 25 & Tároló \\
\hline Gizella & & & 40 & Orvosi szoba \\
\hline & & Helga & 11 & Kis kórterem \\
\hline & & Ildikó & 15 & Nagy kórterem \\
(,elől”)
\end{tabular}

\section{Köszönetnyilvánítás}

Az egészségügyben aktuális kérdések iránti elköteleződésemért hálával tartozom Krisztinának és Petinek, áldozatukért és kitartó küzdelmükért. Köszönöm Lázár László kollégám támogatását, valamint a dolgozók és az édesanyák nyitottságát és bizalmát.

\section{Felhasznált irodalom}

Burrell, G., \& Morgan, G. (1979). Sociological Paradigms and Organisational Analysis. Oxford: Heinemann Educational Books Ltd.

Cocowitch, B. V., Orton, S., Daniels, J., \& Kiser, D. (2013). Reframing Leadership Development in Healthcare. OD Practitioner, 45(3), 10-18. Retrieved from https://cdn.ymaws.com/www.odnetwork.org/resource/ resmgr/odp45_3/vol45no3-cocowitch_et_al.pdf 
de Haes, H. (2006). Dilemmas in patient centeredness and shared decision making: A case for vulnerability. Patient Education and Counseling, 62(3), 291-298. https://doi.org/10.1016/j.pec.2006.06.012

French, W. L., \& Bell, C. H. (1995). Organization Development (5th ed.). Prentice-Hall International Inc.

Gelei, A. (2006). A szervezet interpretatív megközelítése. Vezetéstudomány, 38(1 ksz.), 79-97.

Gelei, A. (2020). Szervezetfejlesztés szerepe a sportpszichológiában. In Zs. Imre Tóvári, G. Simonné Goschi, \& Á. Pálvölgyi (Eds.), A sportpszichológia tankönyve. Budapest: Medicina Könyvkiadó (szerkesztés alatt).

Goh, S. C., Chan, C., \& Kuziemsky, C. (2013). Teamwork, organizational learning, patient safety and job outcomes. International Journal of Health Care Quality Assurance, 26(5), 420-432. https://doi.org/10.1108/IJHCQA-05-2011-0032

Horváth, D. (2015). Projektív technikák. In Alternativ kvalitatív kutatási kézikönyv (pp. 279-317). Budapest: Alinea Kiadó.

Kvale, S. (2009). InterViews. An introduction to qualitative research interviewing. Thousand Oaks: SAGE Publications.

Long, S. (2001). Cooperation and conflict: two sides ot the same coin. In R. Wiesner \& B. Millett (Eds.), Management and Organisational Behaviour (pp. 95-108). Milton: John Wiley and Sons Australia Ltd.

Málovics, É., Vajda, B., \& Kuba, P. (2009). Paternalizmus vagy közös döntés? Páciensek az orvos-beteg kommunikációról. In E. Hetesi, Z. Majó, \& M. Lukovics (Eds.), A szolgáltatások világa (pp. 250-264). Szeged: JATEPress.
Mason, J. (2005). Kvalitatív kutatás. Budapest: Jószöveg Mühely.

PAF Közhasznú Alapítvány. (2020). Pozitiv Attitüd Formálás. Az emberibb egészségügyért. Retrieved from www.pafhungary.hu

Ratnapalan, S., \& Uleryk, E. (2014). Organizational Learning in Health Care Organizations. Systems, 2(1), 24-33. https://doi.org/10.3390/systems2010024

Senge, P. M. (1998). Az ötödik alapelv. Budapest: HVG Kiadó.

Stoelwinder, J. U., \& Clayton, P. S. (1978). Hospital Organization Development: Changing the Focus from 'Better Managenment' to „Better Patient Cared. The Journal of Applied Behavioral Science, 14(3), 400-414.

https://doi.org/10.1177/002188637801400314

Szeverényi, P. (2008). A családközpontú szülészeti gyakorlat lehetöségei a lelki egészség megörzésében. Nőgyógyászati és Szülészeti Továbbképző Szemle. Retrieved from http://medicalonline.hu/gyogyitas/ cikk/a_csaladkozpontu_szuleszeti_gyakorlat_lehetosegei_a_lelki_egeszseg_megorzeseben

Tempfer, C. B., \& Nowak, P. (2011). Consumer participation and organizational development in health care: A systematic review. Wiener Klinische Wochenschrift, 123(13-14), 408-414. https://doi.org/10.1007/s00508-011-0008-x

Verdes (2020). Megértés az együttműködés szolgálatában 1. rész - Az együttműködés megértésének lehetőségei egy egészségügyi szervezetben. Vezetéstudomány, 51(10), 29-39. https://doi.org/10.14267/VEZTUD.2020.10.03

Wollnik, M. (1995). Interpretatív megközelítések a szervezetelméletben. In A. Kieser (Ed.), Szervezetelméletek (pp. 359-383). Budapest: Aula Kiadó Kft. 